\title{
Revue
}

\section{Pig husbandry in Papua New Guinea A bibliography 1863-1979}

\author{
Ann B. COOPER *, J.J. LAUVERGNE **, G.L. MALYNICZ *** \\ and A.R. QUARTERMAIN **** \\ * Laboratoire d'Ethnobotanique et d'Ethnozoologie, Muséum d'Histoire naturelle, \\ 43, rue Cuvier, F 75005 Paris \\ ** I.N.R.A., Laboratoire de Génétique factorielle, \\ Centre de Recherches zootechniques, \\ F 78350 Jouy-en-Josas \\ **: Department of Primary Industry, Livestock Branch, \\ PO BOX 2417, Konedobu, Papua New Guinea \\ **** The University of Papua New Guinea, Department of Agriculture, \\ PO BOX 793, Lae, Papua New Guinea
}

\begin{abstract}
Summary
A chronological list (beginning in 1863) and containing 267 references from 164 authors devoted to pig husbandry in Papua New Guinea is presented. Books and articles written by 142 authors and concerning over 45 different populations are mentionned. This is definitely not an exhaustive bibliography but it does review a dramatic increase in publications on this subject since the 1950's, and mainly in the 1970's due on the one hand to the opening of the Highlands and on the other to the recent development of zootechnical and ethnographic interests in this area.
\end{abstract}

\section{Introduction}

The domesticated pig has been associated with traditional agriculture in Papua New Guinea (1) for probably as long as 5000 years. In recent times, new systems of pig husbandry have become prominent with increasing commercialisation and the introduction of exotic breeding stock. The pig is likely to retain its vital role in rural society and to increase in economic importance with continuing rural development.

This paper is a first attempt to provide a comprehensive bibliography for the use of research workers, students and technical officers involved in pig husbandry development.

(1) See map in fig. 1. 
Ann. B. COOPER et al.

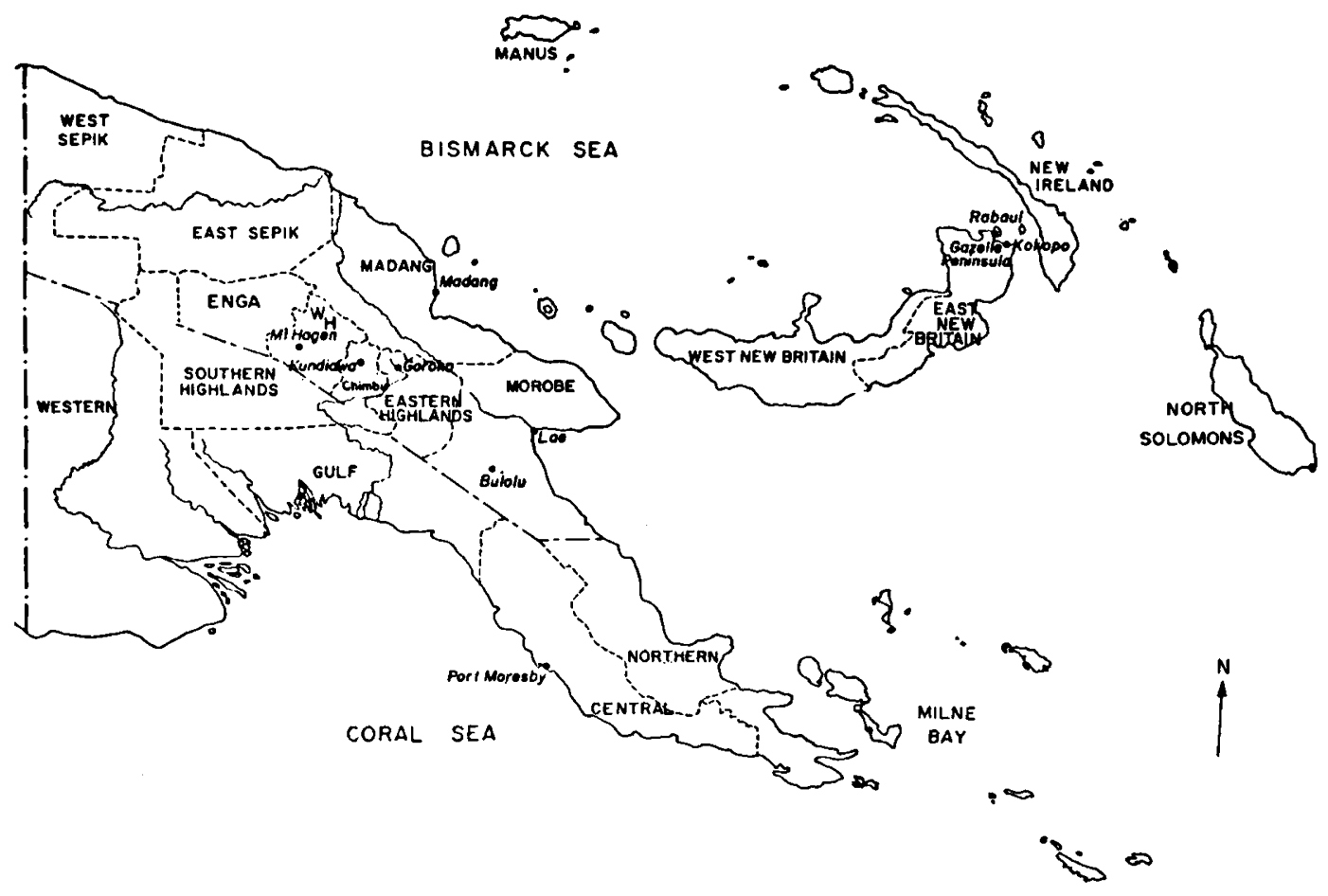

FIG. 1

Papua New Guinea

Papouasie - Nouvelle Guinée

\section{Material and methods}

\section{A. - Sources}

Various sources have been used :

1) The bibliographies provided by authors such as HAYs (1976) and other anthropologists who have worked in Papua New Guinea.

2) Classified abstracts in : Animal Breeding Abstracts, Bulletin Signalétique du C.N.R.S., Abstracts in Anthropology, etc.

3) Articles in journals such as : American Anthropologist, Ethnology, Journal de la Société des Océanistes, Mankind, Oceania, Southwestern Journal of Anthropology.

4) Card catalogues and collections in libraries of the following institutions : Collège de France (Paris), Laboratoire d'Ethnobotanique et d'Ethnozoologie du 
Muséum d'Histoire Naturelle (Paris), Muséum d'Histoire Naturelle (Bibliothèque Centrale), Musée de l'Homme (Paris), Maison des Sciences de l'Homme (Paris), Centre National de Recherches Zootechniques, I.N.R.A. (Jouy-en-Josas), Department of Primary Industry, Papua New Guinea, Papua New Guinea University of Technology, Lac.

5) Bibliographic basis on line : Lockeed (California), Animal Breeding listings and I.A.E.A. (Vienna, Austria) covering years from 1975 to 1980.

\section{B. - Verification of articles}

The articles and books available were consulted. Other bibliographic information was obtained from abstracts or simply from authors' references.

$$
\text { C. - Presentation }
$$

Complete (or sometimes incomplete) references have been organised and numbered chronologically. Indexes according to authors, subjects and peoples are presented.

\section{3. - Chronological bibliographic list}

1863

1863.01 - BREHM A., 1863. Ergebnisse einer Reise nach Masbesch. Hamburg (quoted by Epstein, 1971, vol. 2).

1891

1891.01 - Codrington R.H., 1891. The Melanesians : Studies in their Anthropology and Folklore. Clarendon Press, Oxford (1957 : H.R.A.F. Press, New Haven).

$$
1899-1900
$$

1899.01 - STEhliN G.H., 1899-1900. Ũber die Geschichte der Suidengebisses. Abh. Schweiz. Pal. Ges., 26, 27.

1911

11.01 - BauschKe H., 1911. Beitrag zur Kenntnis der Schweinerassen in den deutschen Kolonien der Südsee. Arch. Naturgesch., 77, 1.

27.01 - Landtman G., 1927. The Kiwai Papuans of British New Guinea. Mac Millan, London. 
1928

28.01 - Willings F.E., 1928. Orokaiva Magic. Oxford University Press, London.

1930

30.01 - Willinms F.E., 1930. Orokaiva Society. Oxford University Press, London.

1933

33.01 - Powdermaker H., 1933. Life in Lesu. The Study of a Melanesian Society in New Ireland. William and Norgate, Ltd., London.

1934

34.01 - Mead M., 1934. How the Papuan plans his dinner. Nat. Hist., 34, 377-388.

34.02 - Thurnwald R.G., 1934. Pigs and Currency, in BuIN : observations about primitive standards of value and economy. Oceania, 5, 119-141.

34.03 - Todd J.A., 1934. A Report on Research Work in South-West New Britain, Territory of New Guinea. Oceania, 5, 80-101, 193-213.

1935

35.01 - Blackwood B., 1935. Both Sides of Buka Passage : an ethnographic study of social and economic questions in Northwestern Solomon Islands. Clarendon Press, Oxford.

35.02 - Lehner S., 1935. The Balum Cult of the Bukaua of the Huon Gulf, New Guinea. Oceania, 5 (3).

1936

36.01 - Williams F.E., 1936. Papuans of the Trans-Fly. Clarendon Press, Oxford.

1937

37.01 - Leahy M.J., Crain M., 1937. The Land that Time forgot. Hurst and Blackett, London.

37.02 - Mead Margaret, 1937. Cooperation and Competition among Primitive Peoples. McGraw-Hill, New York.

1940

40.01 - Williams F.E., 1940. Natives of lake Kutubu, Papua. Oceania, 11, 121-157. 


\section{1}

41.01 - Kaberry P., 1941. The Abelam tribe, Sepik district, New Guinea. Oceania, 11, 345-367.

41.02 - Williams F.E., 1941. Natives of Lake Kutubu, Papua. Oceania, 11, 259-297, 374-401.

1947

47.01 - Bell F.L.S., 1947. The place of food in the social life of the Tanga. Oceania, 18, 36-59.

47.02 - Hogbin H.I., 1947. Pagan Religion in a New Guinea Village. Oceania, 18 (2).

1949

49.01 - Oliver D., 1949. Studies in the anthropology of Bougainville, Solomon Islands. No. 3 : Economic and social uses of domestic pigs in Sinuai, Southern Bougainville. Harvard University Press, Cambridge.

1950

50.01 - Blackwood B., 1950. The Technology of a Modern Stone Age People in New Guinea. Oxford University Press, Oxford.

50.02 - Nilles J., 1950. The Kuman of the Chimbu region, Central Highlands, New Guinea. Oceania, 20, 25-65.

1951

51.01 - Bus G.A.M., 1951. The Te festival or gift exchange in Enga (Central Highlands of New Guinea). Anthropos, 46, 813-824.

1952

52.01 - READ K.E., 1952. Nama cult of the Central Highlands of New Guinea. Oceania, 23, 1-25.

\section{3}

53.01 - ElkiN A.P., 1953. Delayed exchange in Wabag sub-district, Central Highlands of New Guinea, with notes on the social organization. Oceania, 23, 161-201.

1954

54.01 - Laurie E.M.O. and Hill J.E., 1954. List of land Mammals of New Guinea, Celebes and Adjacent Islands 1758-1952. British Museum, London. 
54.02 - LuzebetaK L.J., 1954. The Socio-religious significance of a New Guinea pig festival, parts I and II. Anthropol. Quar., 27, 59-80, 102-128.

54.03 - READ K.E., 1954. Cultures of the Central Highlands, New Guinea. Southwest. J. Anthropol., 10, 1-42.

\section{5}

55.01 - Barrau J., 1955. L'agriculture vivrière mélanésienne. Commission du Pacifique Sud, Nouméa.

55.02 - Oliver D.L., 1955. A Solomon Island Society. Kinship and leadership among the Sinai of Bougainville. Harvard University Press, Cambridge Mass.

\section{6}

56.01 - Hoekstra P., 1956. Veeteelt in Nieuw-Guinea (Animal Breeding in New Guinea). Tijdschr. Diergeneesk, 81, 1119-1121.

57.01 - Held G.H., 1957. The Papuans of Waropen. Martinus Nijhoff, The Hague.

\section{8}

58.01 - Hoekstra P., 1958. Wat kan Australisch Nieuw-Guinea Nederlands NieuwGuinea op veeteel gebied leren ? (What can Australian New Guinea teach Dutch New Guinea in the field of animal breeding ?). Tijdschr. Diergeneesk, 83, 1136-1140.

58.02 - Luzbetak L.J., 1958. The Middle Whagi culture : a study of first contacts and initial selectivity. Anthropos, 53, 51-87.

58.03 - Meggitt M.J., 1958. The Enga of the New Guinea Highlands : some preliminary observations. Oceania, 23, 253-330.

58.04 - Pospisil L., 1958. Kapauku Papuans and their Law. Yale University Press, New Haven.

\section{9}

59.01 - Brown Paula and Brookfield H.C., 1959. Chimbu Land and Society. Oceania, 30, 1-75.

59.02 - Emmanuel M.L., 1959. Leptospirae infections in Papua. Papua and New Guinea med. J., 3, 76.

59.03 - Glasse R.M., 1959. Revenge and redress among the Huli, a preliminary account. Mankind, 5, 273-289.

59.04 - ReAY M., 1959. The Kuma : Freedom and Conformity in the New Guinea Highlands. Melbourne University Press, Melbourne. 
60.01 - Airchison T.G., 1960. The Pig and its place in the impact of the New Guinean on vegetation. Symp. on the Impact of Man on Humid Tropics Vegetation, Goroka, 158-167.

60.02 - Bulmer R., 1960. Political Aspects of the Moka ceremonial exchange system among the Kyaka people of the Western Highlands of New Guinea. Oceania, 31, 1-13.

60.03 - Bulmer R.N.H., 1960. Leadership and social structure among the Kyaka people of the Western Highlands District of New Guinea. Ph. D. thesis, A.N.U., Canberra.

\section{1}

61.01 - Aufenanger H., 1961. Nose-piercing, stone adzes and pig traps at Mundanghai (New Guinea). Anthropos, 56, 940-41.

61.02 - Couvee L.M.J., Rijpstra A.C., 1961. The Prevalence of Balantidium coli in the Central Highlands of Western New-Guinea. Trop. Geogr. Med., 13, 284-286.

61.03 - Oosterwal G., 1961. People of Tor : a Cultural-anthropological Study of the Tribes of the Tor Territory. Van Gorcum, Assen, Netherlands.

61.04 - Papua and New Guinea (Territory of) : Department of Agriculture, Stock and Fisheries, 1961. Annual Report 1955-1960. D.A.S.F., Port Moresby.

61.05 - Ryan D.J., 1961. Gift exchange in the Mendi Valley. PhD. thesis, Sydney University.

61.06 - VAyda A.P., Leeds A., Smith D.B., 1961. The place of pigs in melanesian subsistance, in : Garfield, ed. Symposium : Patterns of Land Utilization and other papers, 69-77. Proc. 1961, Ann. Spring Meet. Am. Ethnol. Soc.

\section{2}

62-01 - Berndt R.M., 1962. Excess and Restraint. Social Control among a New Guinea mountain People. University of Chicago Press, Chicago.

62.02 - Howlett D., 1962. A decade of change in the Goroka valley, New Guinea. Land use and development in the 1950's. PhD. thesis, A.N.U., Canberra.

62.03 - REAY M., 1962. The sweet witchcraft of Kuma dream experience. Mankind, 5 (11), 459-463.

62.04 - SAlisbury R.F., 1962. From stone to steel : economic consequences of technological change in New Guinea. Cambridge University Press, Melbourne. 
62.05 - Venkatachalam P.S., 1962. A study of the diet, nutrition, and health of the people of the Chimbu area. Dept. Public Health monograph no. 4, Konedobu, Papua New Guinea.

\section{3}

63.01 - Brookfield H.C. and Brown Paula, 1963. Struggle for Land : Agriculture and Group Territories among the Chimbu of the New Guinea Highlands. Oxford University Press, Melbourne.

63.02 - Murrel T.G.C. and Roth L., 1963. Necrotizing Jejunitis : A newly discovered disease in the Highlands of New Guinea. Med. J. Aust., 1963, 61-69.

63.03 - Papua and New Guinea (Territory of) : Department of Agriculture, Stock and Fisheries, 1963. Annual Report, 1960-1961. D.A.S.F. Port Moresby.

63.04 - Pospisil L.P., 1963 : The Kapauku Papuans of West New Guinea. Holt, Rinehart, Winston, New York.

63.05 - PosPIsIL L.P., 1963. Kapauku Papuan Economy (Yale University publications in Anthropology no. 67). Yale University New Haven.

63.06 - Thiel P.H. van, Hoeven J.A. Van der, Couvee L.M.J., 1963. Leptospirosis in the Highlands of West New Guinea. Trop. Geogr. Med., 15, 70-75.

63.07 - Zeuner F.E., 1963. A History of Domesticated Animals. Hutchinson, London.

\section{4}

64.01 - Aufenanger H., 1964. Women's lives in the Highlands of New Guinea. Anthropos, 59.

64.02 - Egerton J.R. and Rothwell T.L.W., 1964. The distribution of infectious and parasitic diseases of animals in Papua and New Guinea. Research Bulletin no. 1. Veterinary Science Series, D.A.S.F., Port Moresby, 31 p.

64.03 - Norris K.R. and Murray M.D., 1964. The Screw Worm problem. Aust. vet. J., 40, 148.

64.04 - Rampling A.M., 1964. Porcine melioidosis in the Territory of Papua and New Guinea. Aust. vet. J., 40, 241.

64.05 - Watson J.B., 1964. New Guinea. The Central Highlands. Am. Anthropol., 66 (special publication).

65.01 - Berndt R.M., 1965. The Kamano, Usurufa, Jate and Fore of the Eastern Highlands, in : Lawrence P. and Meggitt M.J., Gods, Ghosts and Men in Melanesia. Oxford University Press, Melbourne. 
65.02 - Bulmer R.N.H., 1965. The Kyaka of the Western Highlands, in : LAwRence P. and MeggitT M.J., Gods, Ghosts and Men in Melanesia. Oxford University Press, Melbourne.

65.03 - Egerton J.R., 1965. Porcine anthrax in Papua and New Guinea. P.N.G. agric. J., 17, 141-144.

65.04 - Glasse R.M., 1965. The Huli of the Southern Highlands, in : Lawrence P. and MegGitt M.J., Gods, Ghosts and Men in Melanesia. Oxford University Press, Melbourne.

65.05 - Meggitt M.J., 1965. The Lineage System of the Mae Enga. Barnes and Noble, New York.

65.06 - Meggitt M.J., 1965. The Mae Enga of the Western Highlands, in : Lawrence P. and Meggitt M.J., Gods, Ghosts and Men in Melanesia. Oxford University Press, Melbourne.

65.07 - Newman P.L., 1965. Knowing the Gururumba. Holt, Rinehart, Winston, New York.

65.08 - Papua and New Guinea (Territory of) : Department of Agriculture, Stock and Fisheries, 1965. Annual Report 1963-1964. D.A.S.F., Port Moresby.

65.09 - Salisbury R.F., 1965. The Siane of the Eastern Highlands, in : LawRence P. and Meggitt M.J., Gods, Ghosts and Men in Melanesia. Oxford University Press, Melbourne.

65.10 - Valentine C.A., 1965. The Lakalai of New Britian, in : Lawrence P. and Meggrtr M.J., Gods, Ghosts and Men in Melanesia. Oxford University Press, Melbourne.

65.11 - Watson J.B., 1965. From hunting to horticulture in the New Guinea Highlands. Ethnology, 4, 295-309.

\section{6}

66.01 - BASSETT D., 1966. The role of radiology in the diagnosis and management of Enteritis Necroticaris. P.N.G. Med. J., 9, 60-65.

66.03 - Burmer Susan, 1966. Pig bone from two archaeological sites in the New Guinea Highlands. J. Polynesian Soc., 75, 504-505.

66.04 - Egerton J.R., 1966. Bacteriology of Enteritis Necroticans in New-Guinea Highlands. P.N.G. Med J., 9, 55-59.

66.05 - Harvey P.R., 1966. The role of the Department of Agriculture, Stock and Fisheries in Enteritis necroticans. P.N.G. Med. J., 9, 66-67.

66.06 - McKillop R.F., 1966. A Highland Pig Industry. D.A.S.F. Newsletter, 8 (4), 147-151.

66.07 - Murrell T.G.C., 1966. Some epidemiological features of Pig-bel. P.N.G. Med J, 9, 72-74. 
66.07 - Murrell T.G.C., 1966. Some epidemiological features of Pig-bel. P.N.G. Med. J., 9, 39-50.

66.08 - Murrell T.G.C., 1966. Pig-bel. P.N.G. Med. J., 9, 68.

66.09 - Murrell T.G.C. et al., 1966. «Pig-bel»: Enteritis necroticans. A study in Diagnosis and Management. The Lancet, jan. 1966, 217-222.

66.10 - Murrell T.G.C. et al., 1966. The Ecology and Epidemiology of the Pig-bel syndrome in Man in New Guinea. J. Hyg. (Cambridge), 64, 375-396.

66.11 - Papua and New Guinea Medical Journal [Editorial (2), 9], 1966. Pig-bel and Tropical Diseases, P.N.G. Med. J., 9, 37-38.

66.12 - Papua and New Guinea (Territory of), Department of Agriculture, Stock and Fisheries, 1966 : Annual Report, 1964-1965. D.A.S.F., Port Moresby.

66.13 - Roth L., 1966. Diagnosis and managements of Pig-bel. P.N.G. Med. J., 9, $51-54$.

66.14 - Strathern A., 1966. Despots and directors in the New Guinea Highlands. Man, 1 (n.s.), 356-367.

1967

67.01 - Bulmer R.N.H., 1967. Why is the Cassowary not a bird? A Problem of zoological taxonomy among the Karam of the New Guinea Highlands. Man, 2, 5-25.

67.02 - Harding T.G., 1967. Voyagers of the Vitiaz Strait. A Study of a New Guinea Trade System. University of Washington Press, Seattle and London.

67.03 - LeEs S.H., 1967. Regional integration of pig husbandry in the New Guinea Highlands. Paper presented at the Michigan Academy of Sciences, Annual meeting.

67.04 - LYNCH R., 1967. Household animals and health projects. P.N.G. Med. J., 10 (9).

67.05 - RAPPAPORT R.A., 1967. Pigs for the Ancestors. Ritual in the Ecology of a New Guinea People. Yale University Press, New Haven.

67.06 - RAPPAPORT R.A., 1967. Ritual regulation of environmental relations among a New Guinea people. Ethnology, 6, 17-30.

67.07 - UrbaN M., 1967. Das Tier in den Kulturen der Südsee (Melanesien, Mikronesien, Polynesien und Australien). Stud. gen. Dtsch., 20, 189-198.

67.08 - Wagner R., 1967. The Curse of Sow. University of Chicago Press, Chicago.

1968

68.01 - Brookfield H.C. and White J.P., 1968. Revolution or Evolution in the Pre-History of the New Guinea Highlands. Ethnology, 7, 43-52. 
68.02 - Bulmer R.N.H., 1968. The strategies of hunting in New-Guinea. Oceania, 38, 302-318.

68.03 - Glasse R.M., 1968. Huli of Papua. A Cognatic Descent System. Mouton, Paris and the Hague.

68.04 - LEEUWEN (A. VAN), 1968. Improvement units in the tropics. Veeteelt-Zuivelber., 11, 442-446 (D.U.).

68.05 - Papua and New-Guinea (Territory of) : Department of Agriculture, Stock and Fisheries, 1968 : Annual Report, 1965-1966. D.A.S.F., Port Moresby.

\section{9}

69.01 - Glasse R. and Meggitt M., eds., 1969. Pigs, Pearlshells and Women. Prentice Hall, Englewood Cliffs, N.J.

69.02 - Guiart J., 1969. Programmation et agriculture en Mélanésie. Homme, 9, 107-112.

69.03 - Malynicz G., 1969. The fate of sixteen pigs distributed into a New Guinea Highlands village. Pig production research report no. 1. D.A.S.F., Goroka (unpublished).

69.04 - Nielsen V.A.H., 1969. The Pig and Poultry industries in Papua and New-Guinea. South Pac. Bull., 19, 54-64.

69.05 - Papua and New-Guinea (Territory of) : Department of Agriculture, Stock and Fisheries, 1969 : Annual report, 1966-1967. D.A.S.F., Port Moresby.

69.06 - RuI W., 1969. Piggery enterprise : costs of establishment of piggery enterprise. Unpublished report in Vudal Agricultural College Library.

69.07 - Springhall J.A., 1969. The use of selected local ingredients for pig rations in the Territory of Papua and New-Guinea. P.N.G. Agric. J., 21, 76-87.

69.08 - Strathern A., 1969. Finance and production : two strategies in NewGuinea Highlands exchange systems. Oceania, 40, 42-67.

69.09 - VAYDA I.W., 1969. The dynamics of a New-Guinea Highlands agricultural system. Ph.D. thesis, A.N.U., Canberra.

69.10 - Watson J., 1969. Review of «Pigs for the Ancestors ». Am. Anthropol., 71, 527-529.

\section{0}

70.01 - Anonymous, 1970. Cocoa pods, a valuable feed for Cattle and Pigs. N.G. Bull., 11 (2), 5-7.

70.02 - Anonymous, 1970. Pigs-breed comparisons. N.G. Bull., 11 (1), 29.

70.03 - Bolens J., 1970. Le Sel de la terre, in : Echanges et communications, II, 1327-1330. Mouton, La Haye. 
70.04 - Brown Paula, 1970. Chimbu Transactions. Man, 5, 99-117.

70.05 - Dickinson D. and Dossor C., 1970. World Catalogue of thesis on the Pacific Islands. Doc. monogr. series no. 1. A.N.U. Press, Canberra.

70.06 - Heider K.G., 1970. The Dogum Dani. A Papuan culture in the Highlands of West Guinea. Wenner-Given Foundation for Anthropological Research, New York (Viking Fund Publications in Anthropology no. 49).

70.07 - Hughes I., 1970. Pigs, sago and limestone. The adaptive use of natural enclosures and planted sago in pig management. Mankind, 7, 272-278.

70.08 - KuPE J., 1970. The Effect of three systems of feeding on growth rate, feed conversion and carcase quality. Full feeding and restricted feeding of Pigs. Unpublished report in Vudal Agricultural College Library.

70.09 - Malynicz G.L., 1970. Pig keeping by the subsistence agriculturalist of the New-Guinea Highlands. Search, 1, 201-204.

70.10 - Malynicz G.L., 1970. Pyrethrum marc for Pigs. Harvest, 1, 23.

70.11 - Malynicz G.L., 1970. Research on Pig production. Harvest, 1, 71-72.

\section{1}

71.01 - Anonymous, 1971. Australian Development Bank assists piggeries in NewGuinea. Pig Farmer, 5, 901.

71.02 - Arek T.C.P., 1971. The effect of coconut oil meal in growing pigs rations on performance, carcase measurements and the economics of feeding. Unpublished report in Vudal Agricultural college Library.

71.03 - Brookfield H.C. and Hart D., 1971. Melanesia. Methuen, London.

71.04 - Clarke W.C., 1971. Place and People : An Ecology of a New-Guinea Community. University of California Press, Berkeley.

71.05 - Epstein H., 1971. The Origin of the Domestic Animals of Africa. Africana Publ. Co., New York, 2, 318-319.

71.06 - F.A.O., W.H.O., O.I.E., 1971. Animal Health Yearbook 1970. F.A.O., Rome.

71.07 - Lowman-VaYda C., 1971. Maring big men, in : Berndt R.M. and LaWRENCE P., Politics in New Guinea. University of Western Australian Press, Nedlands.

71.08 - Maino Ch., 1971. The effect of three systems of feeding on growth rate, feed conversion and carcase quality. Unpublished report in the Vudal Agricultural College Library.

71.09 - Malynicz G.L., 1971. Too much protein in pig rations can cause poor growth. Harvest, 1, 151.

71.10 - MalyNicz G.L., 1971. Use of raw sweet potato, raw peanuts and protein concentrate in rations for growing pigs. P.N.G. Agric. J., 22, 165-166. 
71.11 - Meggitt M.J., 1971. From tribesmen to peasants : the case of the Mae Enga of New Guinea, in : Hiatt L.R. and JAYA-Wardena C., Anthropology in Oceania. Angys and Robertson, Sydney.

71.12 - Purdy D.J., 1971. Changing patterns in pig production in Papua NewGuinea. Austr. vet. J., 47, 481-484.

71.13 - RAPPAPORT R.A., 1971. The flow of energy in an agricultural society. Sci. Am., 324 (3), 116-133.

71.14 - Shannon Rosalie, 1971. A study on the subsistence and cash economics of a village adjacent to the urban area of Goroka. D.A.S.F. Goroka.

71.15 - Strathern A., 1971. Pig complex and cattle complex; some comparisons and counterpoints. Mankind, 8, 129-136.

71.16 - Strathern A., 1971. The Rope of Moka. Big Men and Ceremonial Exchange in Mount Hagen, New-Guinea. Cambridge University Press, Cambridge, Mass.

1972

72.01 - Anderson J.L., 1972. Livestock, in : Encyclopedia of Papua and NewGuinea, II, 645-646. Melbourne University Press, Melbourne.

72.02 - Brown Paula, 1972. The Chimbu : a study of change in the New-Guinea Highlands, Schenkman, Cambridge, Massachusetts.

72.03 - Caley J.E., 1972. Salmonella in pigs in Papua New-Guinea. Austr. vet. J., 48, 601-604.

72.04 - Heider K.G., 1972. The Grand Valley Dani Pig feast : a ritual of passage and intensification. Oceania, 42, 169-197.

72.05 - Malynicz G.L., 1972. Agriculture and Nutrition. Working paper to nutrition policy conference, Dept. Pub. Health, Goroka.

72.06 - Meggits M., 1972. System and subsystem : The Te exchange cycle among the Mae Enga. Hum. Ecol., 1, 111-123.

72.07 - Papua New-Guinea (Territory of) : Department of Agriculture, Stock and Fisheries, 1972 : Annual Report, 1967-1969. D.A.S.F., Port Moresby.

72.08 - RYAN D.J., 1972. Te, in : Encyclopedia of Papua and New-Guinea, II, 1114-1115, Melbourne University Press, Melbourne.

72.09 - Sillano J.C., 1972. The supply and demand for beef, poultry and pork in Papua New Guinea, 1965-1980. D.A.S.F., Konedobu.

72.10 - Sorenson E.R., 1972. Socio-ecological change among the Fore of NewGuinea. Curr. Anthropol., 13, 349-372.

72.11 - Strathern A.J., 1972. Moka, in : Encyclopedia of Papua and New-Guinea, II, 788. Melbourne University Press, Melbourne.

72.12 - Strathern A., 1972. One father, one blood; descent and group structure among the Melpa people. Tavistock Publications, London. 
72.13 - Strathern M., 1972. Women in between; female roles in a male world : Mount Hagen, New-Guinea. Seminar Press, London.

72.14 - Talbot N.T., 1972. Incidence and distribution of Helminth and Arthropod parasites of indigenous owned pigs in Papua New Guinea. Trop. Anim. Health Prod., 4, 182-190.

72.15 - Uthardt L., 1972. Pig raising in New Guinea Highlands. Pig Farmer, 6, 772-781.

72.16 - VAYda A.P., 1972. Pigs, in : Encyclopedia of Papua and New-Guinea, II, 905-908. Melbourne University Press, Melbourne.

72.15 - Uthardt L., 1972. Pig raising in New Guinea Highlands. Pig Farmer, Fisheries, 1972 : Raise good pigs, 1, Housing-coastal. D.A.S.F., Konedobu.

72.18 - Papua New-Guinea (Territory of) : Department of Agriculture, Stock and Fisheries, 1972 : Raise good pigs, 2, Housing-coastal, D.A.S.F., Konedobu.

72.19 - Papua New-Guinea (Territory of) : Department of Agriculture, Stock and Fisheries, 1972 : Raise good pigs, 3 : Feeding and management, D.A.S.F., Konedobu.

72.20 - Papua New-Guinea (Territory of) : Department of Agriculture, Stock and Fisheries, 1972 : Raise good pigs, 4 : Breeds, D.A.S.F., Konedobu.

72.21 - Papua New-Guinea (Territory of) : Department of Agriculture, Stock and Fisheries, 1972 : Raise Good Pigs, 5, Marketing, D.A.S.F., Konedobu.

72.22 - Tietze R., 1972. Lukautim Pik. Yangpela Didiman bilong Niugini, Buk 4. Kristen Pres, Madang.

72.23 - Waddell E.W., 1972 : The Mound Builders : Agricultural Practices, Environment and Society in the Central Highlands of New-Guinea. University of Washington Press, Seattle.

72.24 - Watt I., 1972. Feeding sweet potato to pigs. Harvest, 2, 138.

72.25 - WatT I., 1972. Integrated farming, would it work in Papua New-Guinea. Harvest, 2, 110.

72.26 - WatT I., 1972. Pigs - Feeding. Rural science for High Schools no. 1. Educational materials centre, Goroka.

72.27 - Watr I., 1972. Pigs - Breeds and management. Rural science for High Schools no. 2. Educational materials centre, Goroka.

72.28 - Watr I., 1972. Pigs - Housing. Rural science for High schools no. 3. Educational materials centre, Goroka.

72.29 - Watr I., 1972. Pigs - Marketing. Rural science for High Schools no. 4. Educational materials centre, Goroka.

72.30 - White J.P. ,1972. Ol Tumbuna : archaeological excavating in the Eastern Central Highlands, Papua New-Guinea. Terra Australis, 2 (Dept. Prehistory, A.N.U.). 
73.01 - BRookfield H., 1973. Full circle in Chimbu : a study of trends and cycles, in : Brookfield H., The Pacific in Transition. Geographical perspectives on adaptation and change. Edward Arnold, London, 127-160.

73.02 - Davis C., 1973. Report on pig disease projects 1971-1973. D.A.S.F., Central Vet. Lab., Kila Kila.

73.03 - Dornstreich M.D., 1973. Gadio (Enga), Subsistence Ecology. PhD dissertation in Anthropology, Columbia University, University microfilms, Ann Arbor.

73.04 - FEachem R.G.A., 1973 : The Raiapu Enga pig herd. Mankind, 9, 25-31.

73.05 - Harris G.T., 1973. Promoting rural development. New-Guinea and Australia, The Pacific and South East Asia, 8, 51-59.

73.06 - Kimber A.J., 1973. Wet pig dung its effect on sweet potato, in : Workshop on waste recycling systems. D.A.S.F. and U.P.N.G., Port Moresby.

73.07 - Malynicz G.L., 1973. A Bibliography on Pig Husbandry in Papua NewGuinea. Sci. N.G., 1 (2).

73.08 - Malynicz G.L., 1973. Coconut meal for growing pigs. P.N.G. Agric. J., 24, 142-144.

73.09 - Malynicz G.L., 1973. Comparative costs of energy from conventional and non-conventional sources, in : Workshop on waste recycling systems. D.A.S.F. and U.P.N.G., Port Moresby.

73.10 - Malynicz G.L., 1973. A comparison of four types of floor for housing growing pigs in the Highlands. P.N.G. Agric. J., 24, 104-106.

73.11 - MALYNICZ G.L., 1973. Growth and carcase measurements of indigenous and exotic pigs raised in two housing systems in Papua New-Guinea. P.N.G. Agric. J., 24, 23-25.

73.12 - MalYNicz G.L., 1973. The productivity of exotic and indigenous pigs under village conditions, part. I. P.N.G. Agric. J., 24, 16-19.

73.13 - MalYNICZ G.L., 1973. The productivity of exotic and indigenous pigs under village conditions, part. II. P.N.G. Agric. J., 24, 20-22.

73.14 - Malynicz G.L. and NAD H., 1973. The effect of level of feeding and supplementation with sweet potato foliage on growth performance of pigs. P.N.G. Agric. J., 24, 139-141.

73.15 - WAdDELl E.W., 1973. Raiapu Enga adaptive strategies : structure and general implications, in : Brookfield H., The Pacific in Transition. Geographical perspectives on adaptation and change. Edward Arnold, London, 25-54.

73.16 - Watkins R., Mc Millan B., Kelly A., 1973. Porcine Spirurids (Spiruroidea : Ascaropidae) recorded from beetles (Coleoptera: Scarabaeidae) in Papua New Guinea. P.N.G. Agric. J., 24, 49-50. 


\section{4}

74.01 - Copland J.W., 1974. Metastrongylus spp. infections of village pigs in Papua New-Guinea. J. Helminthol., 48, 25-32.

74.02 - Copland J.W., 1974. Swine Pox in Papua New-Guinea. Trop. anim. Health Prod., 6, 153-157.

74.03 - Feachem R., 1974. Faecal coliforms and faecal streptococci in streams in the New-Guinea Highlands. Water Res., 8, 367-374.

74.04 - Hide R., 1974. On the dynamics of some New-Guinea Highland pig cycles. Manuscript (mimeographed), American Museum of Natural History, New York.

74.05 - Mc Arthur M., 1974. "Pigs for the Ancestors» : a review article. Oceania, 45, 87-123.

74.06 - MALYNICZ G.L., 1974. The effect of adding Leucaena Leucocephala meal to commercial rations for growing pigs. P.N.G. Agric. J., 25, 12-14.

74.07 - Malynicz G.L., 1974. The effect of feed restriction on growth performance on pigs. P.N.G. Agric. J., 25, 18-19, 22.

74.08 - Malynicz G.L., 1974. Plantation crop by-products for growing pigs. P.N.G. Agric. J., 25, 20-22.

74.09 - Malynicz G.L., 1974. The role of legumes in non-ruminant nutrition. Sci. N.G. (Univ. Papua), 2, 22-29.

74.10 - Malynicz G.L., 1974. The use of by-products in rations. Proc. P.N.G. Stock feeds Conf., D.A.S.F., Konedobu.

74.11 - Malynicz G.L., 1974. Whole soyabeans, a protein supplement for sweet potato in pig rations. P.N.G. Agric. J., 25, 15-17.

74.12 - MeggitT M.J., 1974. «Pigs are our hearts!». The Te exchange cycle among the Mae Enga of New-Guinea. Oceania, 44, 165-203.

74.13 - Morren G.E.B., 1974. Settlement strategies and hunting in a NewGuinea society. PhD dissertation, Columbia University, University Microfilms, Ann Arbor.

74.14 - WatT I.R., 1974. Projected livestock development and feed requirements of pigs. Proc. P.N.G. Stock feeds Conf., D.A.S.F., Konedobu.

1975

75.01 - AiJMER G. and Glasse R.M., 1975. Ramblings in Huli symbolism. Ethnos, 40, 300-359.

75.02 - Barton C.J.H. and MALYNiCZ G.L., 1975. The effect of whole soyabeans on growth and carcase composition in pigs. Research, reports and reviews. D.A.S.F., Konedobu. 
75.03 - BinNs C.W., 1975. Food volume, a limiting factor in nutrient intake in the Papua New-Guinea Highlands, in : Willson K. and Bourke R.M. Proc. 1975, Papua New-Guinea Food Crops Conf. D.P.I., Port Moresby, 45-52.

75.04 - Bulmer Susan, 1975. Settlement and economy in prehistoric Papua NewGuinea : a review of the archeological evidence. J. Soc. Océanistes, 31, 7-75.

75.05 - Copland J.W., 1975. Capillaria Infections of Pigs : Description of C. papuensis sp. n. and the pathology of natural infections. J. Helminthol., 49, 187-190.

75.06 - Feachem R.G., 1975. Porcs, population et pollution. Bull. Pacif. Sud, 25, 47-51.

75.07 - LAYCOCK D., 1975. Butchering pigs In Buin. J. Polynesian Soc., 84, 203-212.

75.08 - Lehner E., 1975. Myths and stories of Susure, North-East New-Guinea. Anthropos, 70, 739-760.

75.09 - Malynicz G.L., 1975. Brewers grain in pigs rations. Research reports and Reviews. D.A.S.F., Konedobu.

75.10 - Malynicz G.L. and Nad H., 1975. A Comparison between three ways of feeding sweet potato to pork pigs. Research Reports and Reviews. D.A.S.F. Konedobu.

75.11 - Malynicz G.L., 1975. The effect of floor space per pig on growth performance. Research, Reports and Reviews. D.A.S.F., Konedobu.

75.12 - MalYNicz G.L. and NaD H., 1975. The effect of fresh coconut meat on performance and carcase quality and fat composition of growing pigs. Research Reports and Reviews. D.A.S.F., Konedobu.

75.13 - Malynicz G.L., 1975. Grazing pigs on sweet potato. Research Reports and Reviews. D.A.S.F., Konedobu.

75.14 - Malynicz G.L., 1975. A note on Polydactylism of indigenous pigs in Papua New-Guinea. Research Reports and Reviews. D.A.S.F., Konedobu.

75.15 - Malynicz G.L., 1975. Preliminary information on the effect of Lehmann feeding of sweet potato on carcase quality on pigs. Research Reports and Reviews. D.A.S.F., Konedobu.

75.16 - Malynicz G.L., 1975. Protein supplements for tapioca feeding of growing pigs. Research Reports and Reviews. D.A.S.F., Konedobu.

75.17 - Malynicz G.L., 1975. Research for the smallholder pig farmer in Papua New-Guinea - a basis for Development. Proc. III World Conf. Anim. Prod., 3 (9), 8. University of Sydney Press, Sydney.

75.18 - Malynicz G.L., 1975. A survey of the breeding performance of exotic, indigenous and crossbred breeds of swine in New-Guinea. Research, Reports and Reviews. D.A.S.F., Konedobu. 
75.19 - Malynicz G.L. and Nad H., 1975. Tuna offal for Growing Pigs. P.N.G. Agric. J., 26, 20-22.

75.19 bis - Mikloucho-McLay, 1975. New-Guinea Diaries 1871-1883. Kristen Press, Madang.

75.20 - Rose C.J., 1975. A tethering system of grazing pigs on sweet potatoes in the Tari valley, in : Willson K., Bourke R.M., Proc. 1975, Papua NewGuinea Food Crops Conf., D.P.I., Port Moresby, 151-158.

75.21 - SalisbuRY R.F., 1975. Non-equilibrium models in New-Guinea ecology : possibilities of cultural extrapolation. Anthropologica (Can.), 2 (17), 127-147.

75.22 - Sewell L.N. and Malynicz G.L., 1975. Oil palm fruits for pigs. Research reports and reviews. Pig research section, D.A.S.F., Port Moresby.

75.23 - Shepherd I.J. and Malynicz G.L., 1975. Rotational Grazing of Growing Pigs on Sweet Potato. Research Reports and Reviews, D.A.S.F., Konedobu.

75.24 - Turner W.J. and Malynicz G.L., 1975. Chemical Composition of Some Potential Papua New-Guinean Stock Feed Ingredients. Sci. N.G., 3, 115-116.

75.25 - Watt I.R., McKillop R.F., Penson P.J. and Robinson N.A., 1975. No. 5 Pig Handbook. Rural Development Series, Handbook No. 5. D.A.S.F., Port Moresby, 100 p. (Revised, 1977).

75.26 - Watt I. and Michell F., 1975. Pigs and poultry in the South Pacific. Sorrett Publishing, Malvern, Australia.

\section{6}

76.01 - Cooper Ann B., 1976. Ethnologie du porc en Mélanésie. Pratiques d'élevage et consommation. Ethnozootechnie, 16, 156-167.

76.02 - Copland J.W., 1976. Normal haematological parameters of pigs in Papua New-Guinea. Tropic. Anim. Health Prod., 8, 63-69.

76.03 - Copland J.W., 1976. Some normal biochemical parameters of pigs in Papua New-Guinea. Trop. Anim. Health Prod., 8, 71-81.

76.04 - Copland J.W., 1976. A study of acute «Short Wind» (pneumonia) in village pigs of Papua New-Guinea. Trop. Anim. Health. Prod., 8, 187-194.

76.05 - GAJDUSEK D.C., 1976. Urgent opportunistic observations : the study of changing transient and disappearing phenomena of medical interest in disrupted primitive human communities, in : Health and Disease in Tribal Societies, Ciba Formation Symposium 49 (New series), London, 28-30 sept. 1976. Elseviers Excerpta Medica, North Holland, Amsterdam.

76.06 - HaYs T.E., 1976. Anthropology in the New-Guinea Highlands : an anotated bibliography. Garland reference library of social science, 17, New York and London. 
76.07 - Jones H.I., 1976. The role of pigs in the dissemination of Ascaris and hookworm infections in Papua New-Guinea. P.N.G. Med. J., 19, 193-155.

76.08 - Schieffelin E.L., 1976. The Sorrow of the Lonely and the Burning of the Dancers. St. Martin's Press, New York.

76.09 - Thомаs D.J., 1976. Interpretation of social profiles of production of Tsembaga-Maring, Simbai Valley, Eastern Highlands, New-Guinea. Oceania, 47, 21-35.

1977

77.01 - Bayliss-Smith T.P., 1977. Energy use and economic development in Pacific communities, in : Bayliss-Smith J.P. and Feachem R.G., Subsistence and survival. Rural Ecology in the Pacific, 317-359. Academic Press, London.

77.02 - Bulmer Susan, 1977. Between the mountain and the plain : prehistoric settlement and environment in the Kaironk Valley, in : Winslow J., The Melanesian environment, Ninth Waigani Seminar, 1975, Port Moresby, A.N.U., Camberra, 61-73.

77.03 - Chowing A., 1977. An introduction to the peoples and cultures of Melanesia (second edition), Cummings Publishing, Menlo Park.

77.04 - Dornstreich M.D., 1977. The ecological description and analysis of tropical subsistence patterns : An example from New-Guinea, in : BAYLISsSmith T. and Feachem R.G., eds., Subsistence and survival. Rural Ecology in the Pacific, 245-271. Academic Press, London.

77.05 - F.A.O. Production Yearbook, 1977, tabl. 81, p. 202.

77.06 - FEACHEM R.G.A., 1977. Environmental health engineeringe as human ecology an example from New-Guinea, in : BAYLISS-SMITH T. and FEACHEM R.G., Subsistence and survival. Rural Ecology in the Pacific, 129-182. Academic Press, London.

77.07 - Hallpike C.R., 1977. Bloodshed and vengeance in the Papuan Mountains. The generation of conflict in Tauade society. Clarendon Press, Oxford.

77.08 - Kelly R.C., 1977. Etoro social structure. A study in structural contradiction. University of Michigan Press, Ann Arbor.

77.09 - Mc Arthur M., 1977. Nutritional research in Melanesia : a second look at the Tsembaga, in : BAYLISs-Smith T. and FeACHEM R.G., Subsistence and survival. Rural Economy in the Pacific, 91-128. Academic Press, London.

77.10 - Malynicz G.L., 1977. A demographic analysis of village pig production, in : ENYI B.A.C. and VARghese T., Tenth Waigani Seminar on Agriculture in the Tropics, L.A.E., 1976, U.P.N.G., Port Moresby, 201-209.

77.11 - Malynicz G.L., Asare B., Bunning A., Watt I.R., 1977. A survey of smallholder piggeries in the Highlands, in : ENYI B.A.C. and VARGHESE T., 
Tenth Waigani Seminar on Agriculture in the Tropics, Lae, U., 1976 (presented at). D.P.I., Port Moresby.

77.12 - MorRen G.E.B., 1977. From hunting to herding : pigs and the control of energy in Montane New-Guinea, in : BAYLISs-Smith T. and FEACHEM R.G., Subsistence and survival. Rural Ecology in the Pacific, 273-315. Academic Press, London.

77.13 - Quartermain A.R., 1977. Pigs, goats and people - on the role of animal husbandry in tropical subsistence agriculture, in : ENYI B.A.C. and Varghese T., Tenth Waigani Seminar on Agriculture in the Tropics, Lae, 1976, U.P.N.G., Port Moresby, 54-60.

77.14 - SMITH J.M.B., 1977. Man's impact upon some New-Guinea mountain ecosystems, in : Bayliss-Smith T. and FeAchem R.G., Subsistence and survival. Rural ecology in the Pacific, 185-214. Academic Press, London.

77.15 - VARghese T., 1977. Coccidiosis as a disease of domestic animals and wildlife in Papua New-Guinea, in : ENY B.A.C. and VARGHESE T., Tenth Waigani Seminar on Agriculture in the Tropics, Lae, 1976, U.P.N.G., Port Moresby, 344-353.

77.16 - Watson J.B., 1977. Pigs, fodder and the Jones effect in Post-ipomoean New-Guinea, Ethnology, 16, 57-70.

1978

78.01 - Brown Paula, 1978. Highland Peoples of New Guinea. Cambridge University Press, Cambridge.

78.02 - Densley D.R.J. with Purdy D.J., Malynicz G.L., Cairns I.J., Herington P., Simmons G., Rouse T., Sadler G. and Balachandran N., 1978, Livestock. Agriculture in the economy, a series of review papers. D.P.I., Port Moresby.

78.03 - DwYer P.D., 1978. Rats, Pigs and Man : disturbance and diversity in the New Guinea Highlands in rain forest and grass land habitats. Aust. Ecol., 3, 213-232.

78.04 - JefFries D., 1978. Food habits in rural and urban environments : an example from Papua New-Guinea, Proc. Nutr. Soc. Austr., 3, 45-56.

78.05 - Malynicz G.L., 1978. The development of pig production in the tropics, in : International Training Course : Pig Husbandry : selected discussion papers. Australian Development Assistance Bureau, Dept. of Foreign Affairs, Canberra, 146-152.

78.06 - Malynicz G.L., 1978. Pig breeds for the Tropics, in : International Training Course : Pig Husbandry : selected discussion papers, Australian Development Assistance Bureau, Dept. of Foreign Affairs, Canberra, 153-157.

78.07 - MALYNICZ G.L., 1978. Smallholder pig feeding systems for the Tropics, in : International Training Course : Pig Husbandry : selected discussion 
papers. Australian Development Assistance Bureau, Dept. of Foreign Affairs, Canberra, 162-164.

78.08 - Papua New-Guinea : Department of Agriculture, Stock and Fisheries, 1978 : Fattening Pigs. Farming Notes Series, no. 24, D.A.S.F., Port Moresby.

78.09 - Ross J., 1978. Diseases of pigs in Papua New-Guinea, in : International Training course : Pig Husbandry : selected discussion papers. Australian Development Assistance Bureau, Dept. of Foreign Affairs, Canberra, 165-173.

78.10 - Springhall J.A., 1978. Composition of a number of tropical and subtropical feedstuffs, in : International Training Course : Pig Husbandry, Selected discussion papers. Australian Development Assistance Bureau, Dept. of Foreign Affairs, Canberra, 141-145.

\section{9}

79.01 - Leroy J.D., 1979. The ceremonial pig kill of the South Kewa. Oceania, 49, $179-209$.

79.02 - Morren G.E.B., 1979. Seasonality among the Miyanmin : wild pigs, movement and dual kinship organization. Mankind, 12, 1-12.

79.03 - Quartermain A.R., 1979. Sector paper on Livestock. South Pacific Agricultural Survey 1979. Asian Development Bank, 66 p.

79.04 - Sack P. and Clark D., 1979. German New-Guinea. The Annual Reports. A.N.U. Press, Canberra.

\section{4. - Indexes}

\section{A. - Author index}

Aljmer G., 75.01.

AITCHISON T.G., 60.01.

ANDERSON J.L., 72.01.

ANONYMous, 70.01, 70.02, 71.01.

AREK T.C.P., 71.02.

ASARE B., 77.11.

Aufenanger H., 61.01, 64.01.

BalachandRaN N., 78.02.

BARRAu J., 55.01.

BARTON C.J.H., 75.02.

BASSETT D., 66.01 .

BAuschKe H., 11.01.

BAYLISS-SMITH T., 77.10.

BELL F.L.S., 47.01.

BERNDT R.M., 62.01, 65.01 . 
BinNS C.W., 75.03.

BLACK R.H., 66.02.

BlaCKBURN C.R., 66.02 .

BLACKWOOD B., 35.01, 50.01.

BOLENS J., 70.03.

BREHM A., 1863.01.

BRookfield H.C., 59.01, 63.01, 68.01, 71.03, 73.01.

Brown Paula, 59.01, 63.01, 70.04, 72.02, 78.01.

BULMER R.N.H., 60.02, 60.03, 65.02, 67.01, 68.02.

Bulmer Susan, 66.03, 75.04, 77.02.

BunNing A., 77.11.

Bus G.A.M., 51-01.

CAIRNS I.J., 78.02.

Caley J.E., 72.03.

Chowing A., 77.03.

Clark D., 79.04.

Clarke W.C., 71.04.

Codrington R.H., 1891.01.

Cooper Ann B., 76.01.

Copland J.W., 74.01, 74.02, 75.05, 76.02, 76.03, 76.04.

CouveE L.M.J., 61.02, 63.06.

Crain M., 37.01.

Davis C., 73.02.

DENSLEY D.R.J., 78.02.

DICKINSON D., 70.05.

DORNSTREICH M.D., 73.03, 77.04.

DWYER P.D., 78.03.

Egerton J.R., 64.02, 65.03, 66.04 .

ElKIN A.P., 53.01.

EMmanuel M.L., 59.02.

EPSTEIN H., 71.05.

F.A.O., 71.06, 77.05.

FeACHEM R.G.A., 73.04, 74.03, 75.06, 77.06

GADJUSEK D.C., 76.05.

GlasSE R.M., 59.03, 65.04, 68.03, 69.01.

GUIART J., 69.02.

Hallpike C.R., 77.07.

HARDING T.G., 67.02.

HARRIS G.T., 73.05.

HART D., 71.03.

HARVEY P.R., 66.05 .

HAYS T.E., 76.06.

HeIdER K.G., 70.06, 72.04.

Held G.J., 57.01.

Herington P., 78.02.

HIDE R., 74.04. 
Hill J.E., 54.01.

Hoekstra P., 56.01, 58.01.

HoEven (J.A. VAN DER), 63.06.

HOGBIN H.I., 47.02.

HowletT D., 62.02.

Hughes I., 70.07.

JEFFERIES D., 78.04.

JONES H.I., 76.07.

KABERRY P., 41.01.

KELLY A., 73.16.

KELLY R.C., 77.08.

KIMBER A.J., 73.06.

KupE J., 70.08 .

LANDTMAN G., 27.01.

LAURIE E.M.O., 54.01.

LAYCOCK D., 75.07.

LEAHY M.J., 37.01.

LEEDS A., 61.06.

LEES S.H., 67.03.

LEEUWEN A. VAN, 68.04.

LEHNER E., 35.02.

LEHNER S., 75.08.

LEROY D., 79.10.

LOWMAN-VAYDA, 71.07.

LUZBETAK L.J., 54.02, 58.02.

LYNCH R., 67.04.

MCARThuR M., 75.05, 77.09.

MCKILloP R.F., 66.06, 75.25.

MCMillan B., 73.16.

MaIno C., 71.08.

MALYNICZ G.L., 69.03, 70.09, 70.10, 70.11, 71.09, 71.10, 72.05, 73.07, 73.08, 73.09, $73.10,73.11,73.12,73.13,73.14,74.06,74.07,74.08,74.09,74.10,74.11$, $75.02,75.09,75.10,75.11,75.12,75.13,75.14,75.15,75.16,75.17,75.18$, $75.19,75.22,75.23,75.24,77.10,77.11,78.02,78.05,78.06,78.07$.

MEAD Margaret, 34.01, 37.02.

MegGitT M.J., 58.03, 65.05, 65.06, 69.01, 71.11, 72.06, 74.12.

Michell F., 75.26.

MikLOUCHO-Mc LAY, 75.19 bis.

Morren G.E.B., 74.13, 77.12, 79.02.

MURRAY M.D., 64.03.

MurRel T.G.C., 63.02, 66.02, 66.07, 66.08, 66.09, 66.10.

NAD H., 73.14, 75.10, 75.12, 75.19.

NeWMaN P.L., 65.07 .

NiELSEN V.A.H., 69.04.

Nilles J., 50.02 .

NoRRIS K.R., 64.03 . 
Oliver D., 49.01, 55.02.

Oosterwal G., 61.03 .

PENSON P.J., 75.25.

P.N.G. D.A.S.F., 61.04, 63.03, 65.08, 66.12, 68.05, 69.05, 72.07, 72.17, 72.18, 72.19, $72.20,72.21,78.08$.

P.N.G. Med. J., 66.11 .

POSPISIL L., 58.04, 63.04, 63.05.

Powdermaker H., 33.01 .

PURDY D.J., 71.12, 78.02.

QUARTERMAIN A.R., 77.13, 79.03.

RAMPLING A.M., 64.04.

RAPPAPORT R., 67.05, 67.06, 71.13.

READ K.E., 52.01, 54.03.

REAY M. 59.04, 62.03.

RiJPSTRA A.C., 61.02.

RobINSON N.A., 75.25.

Rose C.J., 75.20.

Ross J., 78.09.

RоTH L., 63.02, 66.13.

ROTHWELL T.L.W., 64.02 .

Rouse T., 78.02.

RUI W., 69.06.

RYAN D.J., 61.05, 72.08.

SACK P., 79.04.

SADLER G., 78.02.

SALISBURY R.F., 62.04, 65.09, 75.21.

SCHIEFFELIN E.L., 76.08.

SEWELL L.N., 75.22.

SHANNON Rosalie, 71.14.

SHEPHERD I.J., 75.23.

Sillano J.C., 72.09 .

Simmons G., 78.02.

SMITH D.B., 61.06.

SMITH J.M.B., 77.14.

SORENSON E.R., 72.10.

SPRINGHALL J.A., 69.07, 78.10.

STRATHERN A., 69.08, 71.15, 71.16, 72.11, 72.12.

STRATHERN M., 66.14, 72.13.

STEHLIN G.H., 1899.01 .

TALBOT N.T., 72.14.

ThIEL (P.H. VAN), 63.06.

Thomas D.J., 76.09.

Thurnwald R.G., 34.02 .

TIETZE R., 72.22.

TODD J.A., 34.03.

TURNeR W.J., 75.24. 
URBAN M., 67.07.

UTHARDT L., 72.15.

VAlentine C.A., 65.10.

VARGHESE T., 77.15.

VAYDA A.P., 61.06, 69.09, 72.16.

Venkatachalam P.S., 62.05.

WADDELL E.W., 72.23, 73.15.

WAGNER R., 67.08 .

WATKINS R., 73.16.

WATSON J.B., 64.05, 65.11, 69.10, 77.16.

WATT I., 72.24, 72.25, 72.26, 72.27, 72.28, 72.29, 74.14, 75.25, 75.26, 77.11.

WHITE J.P., 72.30.

W.H.O.O.I.E., 71.06.

Williams F.E., 28.01, 30.01, 36.01, 40.01, 41.02.

ZEUNER F.E., 63.07.

\section{B. - Subject index}

1. Archeology and Prehistory, 60.01, 64.05, 65.11, 66.03, 68.01, 71.05, 72.01, 72.02, 72.30, 75.04, 77.02.

2. Bibliographies and Reference Material, 75.05, 73.07, 76.01, 76.06, 78.02, 79.04.

3. Breeds and Classification, 1863.01, 1899.01, 11.01, 54.01, 55.01, 56.01, 58.01, $61.04,63.07,65.08,66.12,68.05,69.05,70.02,70.08,71.05,72.01,72.06$, $72.16,72.27,73.11,73.12,73.13,75.14,75.18,78.06$.

4. Demography (Pig), 62.02, 62.05, 63.01, 65.11, 67.05, 67.06, 69.10, 71.04, $72.01,72.10,73.02,73.04,73.15,74.04,75.06,76.09,77.01,77.05,77.10$, $77.12,77.13,79.03$.

5. Description and Farming Systems, 61.04, 63.03, 65.08, 66.12, 67.05, 68.04, $68.05,69.01,69.05,70.06,70.09,73.12,73.13,75.14,75.18,77.10,77.13$, $78.02,78.05,79.03$.

6. Diseases, Human (Related to Pigs and Pork), 27.01, 59.02, 61.02, 63.02, 63.06, $66.01,66.02,66.04,66.05,66.07,66.09,66.10,66.11,66.13,67.04,69.09$, $72.16,73.04,74.03,75.06,76.05,76.07,77.06$.

7. Diseases, Pig, 58.02, 58.03, 64.02, 64.03, 64.04, 67.04, 70.06, 71.06, 72.03, $72.07,72.14,73.02,73.16,74.01,74.02,75.05,75.14,76.02,76.03,76.04$, $78.02,79.09$.

8. Economy Modern (Marketing), 71.14, 72.21, 72.29, 78.02.

9. Economy Traditional (Exchange System) :

a) General, 28.01, 30.01, 34.02, 35.01, 40.01, 49.01, 51.01, 53.01, 58.03, 59.03, $60.01,60.02,60.03,61.05,61.06,62.01,62.04,63.04,63.05,64.05,65.05$, $66.14,67.02,67.05,67.07,67.08,68.01,68.03,69.01,69.08,70.09,71.03$, 
$71.07,71.11,71.15,71.16,72.06,72.08,72.11,72.13,73.04,74.12,77.07$, $77.08,77.10,77.12$.

b) Moka, 60.02, 60.03, 66.14, 69.08, 72.11 .

c) $\mathrm{Te}, 51.01,53.01,58.03,65.05,71.11,72.06,72.08,74.12$.

10. Energy Studies, 67.05, 67.06, 69.09, 71.04, 71.13, 73.15, 75.21, 77.01, 77.04, 77.12 .

11. Feral Pigs and Hunting, 27.01, 28.01, 30.01, 35.01, 36.01, 50.01, 60.01, 61.01, $61.03,62.04,65.11,67.01,67.05,67.08,68.02,70.07,71.16,74.13,76.08$, $77.12,77.14,77.16,79.02$.

12. Horticulture and Natural Vegetation (Effects of Pig on), 58.03, 60.01, 62.04, $63.01,64.01,65.11,67.05,67.06,68.01,69.10,70.06,70.07,70.09,71.03$, $71.04,71.13,72.10,72.16,72.23,72.30,73.03,73.06,74.04,77.01,77.04$, $77.14,78.03$.

13. Husbandry Modern :

a) General, 60.01, 61.04, 66.06, 67.03, 68.04, 69.04, 69.06, 69.07, 69.10, 70.08, $70.09,70.10,70.11,71.01,71.02,71.08,71.09,71.10,71.12,72.20,72.22$, $72.25,72.27,72.28,73.05,73.10,73.11,73.12,73.13,73.14,75.17,75.18$, $75.25,75.26,78.05$.

b) Feeding, 60.01, 61.01, 69.07, 70.01, 70.08, 70.10, 71.02, 71.08, 71.09, 71.10, $72.19,72.24,72.26,73.08,73.09,73.14,74.06,74.07,74.08,74.09,74.10$, $74.11,74.14,75.02,75.09,75.10,75.12,75.13,75.15,75.16,75.19,75.20$, $75.22,75.23,75.24,77.12,78.10$.

c) Housing, 72.04, 72.17, 72.18, 73.10, 73.11, 75.11, 75.17, 77.11.

d) Small Holder Pig Farmers, 75.17, 78.07.

14. Husbandry Traditional :

a) General, 34.02, 35.01, 36.01, 37.02, 47.01, 49.01, 54.03, 58.02, 58.03, 59.04, $60.01,62.04,63.01,63.05,64.01,65.05,65.07,67.05,67.06,67.08,69.01$, $69.02,70.06,70.07,70.09,71.13,71.16,72.10,72.12,72.13,72.15,72.16$, $72.23,73.03,73.04,73.05,73.12,73.13,73.15,77.07,77.08,77.10,78.01$, 78.02 .

b) Feeding, 35.01, 47.01, 49.01, 58.02, 58.03, 59.04, 62.04, 65.05, 67.05, 70.06, $70.07,74.04,77.01,77.16,78.01$.

c) Housing and enclosure, 49.01, 58.03, 62.04, 67.05, 70.06, 70.07, 78.01.

d) Reproduction, 35.01, 47.01, 49.01, 58.03, 62.04, 65.05, 67.05, 70.06, 74.03, 77.10.

15. Land Use, $59.01,62.02,63.01,65.11,67.05,70.07,71.04,72.10,72.23,72.30$, 73.15 .

16. Legislation and Ownership, 37.02, 58.03, 58.04, 65.05, 67.05, 70.06, 72.02, 72.04, 77.07.

17. Magic, $1891.05,27.01,28.01,30.01,33.01,41.01,47.01,58.03,62.04,65.02$, $65.04,65.05,65.07,67.05,70.06,73.04$.

18. Manuals, 72.17, 72.18, 72.19, 72.20, 72.21, 72.22, 72.26, 72.27, 72.28, 72.29. 
19. Pork Production and Consumption :

a) General, 27.01, 28.01, 30.01, 33.01, 34.01, 34.02, 34.03, 35.01, 49.01, 50.01, $52.01,54.02,57.01,58.03,61.06,62.04,62.05,65.05,67.05,67.06,67.07$, $67.08,69.10,70.06,70.09,71.15,71.16,72.04,72.05,72.09,72.12,72.16$, 74.05, 77.07, 78.02, 78.04.

b) Preparation and distribution, 27.01, 28.01, 30.01, 34.02, 35.01, 49.01, 54.02, $57.01,58.03,61.06,62.04,65.05,67.05,67.06,67.08,69.09,70.06,71.16$, 72.04, 75.07, 76.08, 77.07, 77.10.

c) Nutritional value, $61.06,62.05,67.05,67.06,69.09,69.10,71.15,72.05$, $74.05,75.03,77.09,77.12,77.16,78.04$.

20. Religion, Mythology Symbolism, 1891.01, 27.01, 28.01, 30.01, 34.02, 36.01, $47.02,52.01,54.02,54.03,57.01,58.03,60.01,62.03,62.04,65.01,65.02$, $65.04,65.05,65.06,65.07,65.09,65.10,67.01,67.05,67.08,70.03,70.06$, $72.12,75.08$.

21. Ritual Sacrifice, Festival, Pig Cycle, 27.01, 28.01, 30.01, 34.02, 35.01, 35.02, $40.01,47.01,47.02,50.02,52.01,54.02,58.03,59.01,59.03,60.01,60.02$, $60.03,62.01,62.04,63.04,64.05,65.01,65.02,65.04,65.05,65.06,65.07$, $65.09,67.05,67.06,67.08,68.03,69.02,70.04,70.06,71.04,71.15,71.16$, $72.04,72.12,72.13,72.16,73.01,74.04,74.05,74.12,75.01,75.21,77.07$, $77.09,77.10,78.01,79.01$.

22. Social Importance, Prestige, 51.01, 54.02, 58.03, 59.03, 60.01, 62.01, 62.04, $64.01,65.05,66.14,67.05,69.01,70.09,71.07,71.11,71.15,71.16,72.08$, $72.16,73.01,74.12,77.07$.

23. Use of Pig and Pig Products (Non-alimentary), 27.01, 50.01, 58.03, 62.04, 67.05, 70.06, 73.06, 73.09.

\section{C. - Index of peoples and places}

Abelam, 41.01.

Arapesh, 34.01, 37.02.

Bougainville, 49.01.

Buin, 34.02, 35.01, 75.07.

Bukaua, 35.02.

Busana, 47.02.

Central Highlands, 52.01, 54.03, 61.02, 63.02, 63.06, 64.05, 66.04, 66.06, 66.14, $67.03,69.03,69.08,69.09,70.09,71.15,72.23,75.03,76.01,77.10,77.11$, $77.12,77.14,78.01$.

Chimbu, 59.01, 62.05, 63.01, 70.04, 72.02, 73.01, 74.04, 77.10.

Dani, 70.06, 72.04 .

Daribi, 67.08, 70.07.

Enga, 51.01, 58.03, 65.05, 65.06, 71.11, 72.06, 72.23, 73.03, 73.04, 73.15, 74.12, $75.06,77.01,77.04,77.06,77.12$.

Etoro, 77.08 . 
Fore, 65.01, 72.10, 78.04.

Gahaku-Gama, 52.01, 54.03.

Goroka, 62.02, 71.14.

Gururumba, 65.07.

Huli, 59.03, 65.04, 68.03, 75.01, 75.20.

Jate, 65.01 .

Kaironk, 77.02.

Kamano, 65.01.

Kapauku, 58.04, 63.04, 63.05, 64.05.

Karam, 67.01.

Keraki, 36.01.

Kerowagi, 77.10.

Kewa, 79.01.

Kiwai, 27.01.

Kukukuku, 50.01 .

Kuma, 59.04, 62.03.

Kuman, 50.02.

Kutubu, 40.01, 41.02.

Kyaka, 60.02, 60.03, 65.02.

Lakalai, 65.10.

Lesu, 33.01.

Mareng, 67.05, 67.06, 69.10, 71.07, 71.13, 71.15, 74.05, 76.09, 77.07, 77.09, 77.12.

Melpa, 71.15, 71.16, 72.12, 72.13.

Mendi, 61.05 .

Miyanmin, 74.13, 77.02, 77.12.

Mount Hagen, 71.16, 72.13, 77.10.

Mundanghai, 61.01.

New Britain, 34.03.

Orokaiva, 28.01, 30.01.

Siane, 62.04, 65.09, 75.21.

Siuai, 49.01, 55.02.

Stavade, 77.07.

Susure, 75.08.

Tanga, 47.01.

Tor, 61.03 .

Trans Fly, 36.01.

Tundawe, 70.07 .

Usurufa, 65.01.

Vitiaz Straight, 67.02.

Wabag, 53.01.

Wahgi, 54.02, 58.02, 71.15.

Waropen, 57.01. 


\section{5. - Discussion and conclusion}

First of all it must be noted that undoubtely a number of pertinent references have been omitted simply because many journals, books and other useful documents are not always available in France, where the main bibliographic research work was conducted.

In fig. 2 is presented the average annual number of articles devoted to pigs in Papua New-Guinea since 1900.

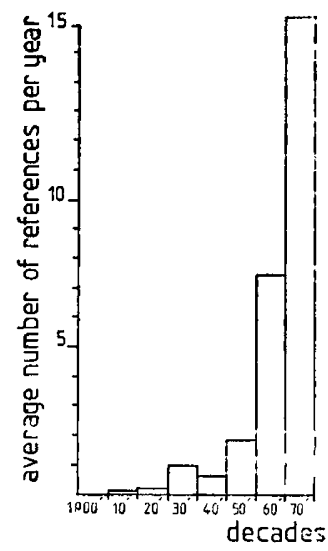

FIG. 2

Per year average number of references in the decades since 1900

Nombre moyen annuel de références par décades depuis 1900

Even considering the inevitable omissions there has been a tremendous increase in the number of publications in the last few decades $(90$ per cent of all the articles of the review have been published since 1950). This is an a posteriori justification for the present bibliography.

The earlier references are mostly accounts written by travellers explorers and naturalists, together with several ethnographic studies concerning coastal and lowland populations. The sudden increase in the number of ethnological publications from the 1950's reflects the post war opening of the Highlands. The development of interest in pig research by the then Department of Agriculture, Stock and Fisheries in the sixties resulted in a new wave of specialised zootechnical articles.

Reçu pour publication en juillet 1981. 


\title{
Acknowledgements
}

This article is the first part of cooperative program France-Papua New-Guinea which is supported by the French Ministry of External Relations, the Department of Primary Industry of Papua New-Guinea and the staff of the University of Papua NewGuinea.

\author{
Résumé \\ L'élevage du Porc en Papouasie Nouvelle-Guinée : \\ une bibliographie - 1863-1979
}

Une liste bibliographique de 267 références concernant l'élevage du Porc en Papouasie Nouvelle-Guinée a été établie. La plus ancienne référence remonte à 1863 . Ces livres et articles ont été écrits par 164 auteurs différents et portent sur plus de 45 peuplades. La liste ainsi établie comporte certainement des omissions mais on distingue déjà très nettement un accroissement considérable du nombre des articles depuis les années cinquante et surtout soixante-dix. Cela est dû d'une part à l'ouverture des Highlands à la pénétration de la civilisation occidentale, et d'autre part à l'intérêt zootechnique et ethnographique porté à cette zone qui va croissant.

\section{Abbreviations}

A.N.U. : Australian National University (Canberra).

C.N.R.Z. : Centre National de Recherches Zootechniques (Jouy-en-Josas, France).

D.A.S.F. : Dept of Agriculture Stock and Fisheries (previous name for D.P.I.).

D.P.I. : Dept of Primary Industry (of P.N.G.).

FA.O. : Food and Agriculture Organisation (Rome).

I.A.E.A. : International Atomic Energy Agency (Vienna).

I.N.R.A. : Institut National de la Recherche Agronomique (France).

N.G. : New-Guinea.

O.I.E. : Office International des Epizooties.

P.N.G. : Papua New-Guinea.

UNITECH : University of Technology (Lae, P.N.G.).

U.P.N.G. : University of Papua New-Guinea (Port Moresby, P.N.G.).

W.H.O. : World Health Organisation. 